\title{
Ny antologi giver inspiration til brug af portfolio
}

\author{
Anmeldelse af Anne Mette Morcke, Enhed for Medicinsk Uddannelse, Det \\ Sundhedsvidenskabelige Fakultet, Aarhus Universitet
}

Portfolio i et lærings- og uddannelsesperspektiv Birthe Lund (red.)

Aalborg Universitetsforlag

2008

168 sider

ISBN: 978-87-7307-931-7

En række uddannelsesudviklere med tilknytning til Institut for Uddannelse, Læring og Filosofi, Aalborg Universitet - Birthe Lund (red.), Kirsten Jæger, Lone Krogh, Anette Lorentsen og Annie Aarup Jensen - har skrevet en antologi om portfolio. Antologien består af seks artikler:

1) Læringsteoretiske begrundelser for portfolien som pædagogisk redskab i en skandinavisk tradition (26 s)

2) Portfolioevaluering og nye eksamensformer (25s)

3) Undervisningsportfolien - muligheder, udfordringer og erfaringer fra adjunktpædagogikum og underviserkvalificeringsforløb ved andre uddannelser (46 s)

4) Indførelse af portfolio som pædagogisk redskab og som struktur for dokumentation af kompetence $i$ kandidatuddannelse - potentialer og udfordringer (35 s)

5) Et organisatorisk perspektiv på portfolio (24s)

De enkelte artikler er genremæssigt forskellige. De tre første artikler har primært lærebogskarakter. De gennemgår teoretiske grundlag og principper og giver et overblik over litteraturen. Dog inddrager den tredje artikel også erfaringer, som forfatterne har gjort sig med anvendelse og udvikling af portfolio som led $i$ underviserkvalificering. Den fjerde artikel præsenterer et empirisk arbejde, som forfatterne har gennemført $i$ forbindelse med indførelse af en e-portfolio på kandidatuddannelsen i læring og forandringsprocesser på Aalborg Universitet. Den sidste artikel tager afsæt i den internationale litteratur og diskuterer organisatoriske aspekter af at indføre portfolio i uddannelser.
Med antologien yder forfatterne et væsentligt bidrag til erfaringsudveksling om portfolio, som er meget velkomment og falder på et tørt sted. Det er på tide, at vi begynder en systematisk diskussion af brugen af portfolio på de danske universiteter. Der er mange guldkorn at hente $i$ antologien, hvor forfatterne generøst deler ud af deres solide viden, rige erfaringer og interessante undersøgelsesresultater. Især påskønnede jeg, at forfatterne ikke kun priser portfolio, men også tager fat i de begrænsninger og udfordringer, som de har oplevet og udforsket.

Jeg har dog også nogle kritikpunkter, der handler om redigering, indeks og målgruppe. Antologier er en vanskelig formidlingsform, hvor der ofte bliver både en del gentagelser og en del huller. Det præger også denne antologi. Især er der en del gentagelser af teoristof igennem de tre første kapitler, hvilket gør, at jeg ikke kan anbefale andre at forsøge sig med en sammenhængende gennemlæsning af bogen. Jeg savner også temmelig meget et indeks. Det er vanskeligt at (gen)finde de forskellige emner. Man må gennemlæse hele artikler eller bladre meget rundt eller give op, hvis man leder efter noget bestemt. Man kan derfor ikke bruge antologien til at slå noget op, hvilket er ærgerligt. Endelig er jeg i tvivl om, hvem der er antologiens målgruppe. Forfatterne skriver ikke selv, hvem de skriver til. Med den store vægt, antologien lægger på basale begreber og teori, så er det næppe erfarne universitetspædagoger eller udviklingscentrene, der er målgruppen. Antologiformen gør, at adjunkter ved sundhedsvidenskab sandsynligvis vil finde den ret vanskelig at læse, og jeg tror, at det samme gælder for adjunkter ved andre 'upædagogiske' fakulteter. En egentlig lærebog ville klart ramme dem bedre. Mit bedste bud på en målgruppe bliver derfor studieledere eller kursusledere, der overvejer at indføre portfolio på deres uddannelser. De universitetspædagogiske udviklingscentre og institutbibliotekerne bør derfor anskaffe sig et eksemplar af antologien, som kan styrke og lede en spirende lyst til at arbejde med portfolio. 